RESIDENT

\& FELLOW

SECTION

Section Editor

Mitchell S.V. Elkind,

MD, MS

G. Della Marca, MD, $\mathrm{PhD}$

S. Dittoni, MD

F. Pilato, MD

P. Profice, MD

A. Losurdo, MD

E. Testani, MD

S. Colicchio, MD

V. Gnoni, MD

C. Colosimo, MD

V. Di Lazzaro, MD

\title{
Teaching NeuroImages: \\ Transient epileptic amnesia
}

A 71-year-old man presented recurrent transient episodes of anterograde and retrograde amnesia, since age 60 years, with a frequency of 10 per month. The attacks, preceded by vague abdominal discomfort, lasted from a few minutes to 2-3 hours. History was unremarkable except for a head trauma; he took no drugs. MRI showed a left meningoencephalocele, likely posttraumatic, in the middle cranial fossa (figure 1). EEG showed left temporal spikes (figure 2). Carbamazepine induced cessation of the seizures. Transient epileptic amnesia is a distinctive syndrome, characterized by recurrent episode of amnesia, symptomatic of an epileptic seizure disorder of temporal lobe origin. ${ }^{1,2}$

\section{REFERENCES}

1. Butler CR, Graham KS, Hodges JR, Kapur N, Wardlaw JM, Zeman AZ. The syndrome of transient epileptic amnesia. Ann Neurol 2007;61:587-598.

2. Butler CR, Bhaduri A, Acosta-Cabronero J, et al. Transient epileptic amnesia: regional brain atrophy and its relationship to memory deficits. Brain 2009;132:357368.

Address correspondence and reprint requests to Dr. Giacomo Della Marca, Department of

Neurosciences, Catholic University, Rome, Italy, Policlinico

Universitario “A. Gemelli” L.go A.

Gemelli, 8-00168 Rome, Italy

dellamarca@rm.unicatt.it

Figure $1 \quad$ MRI
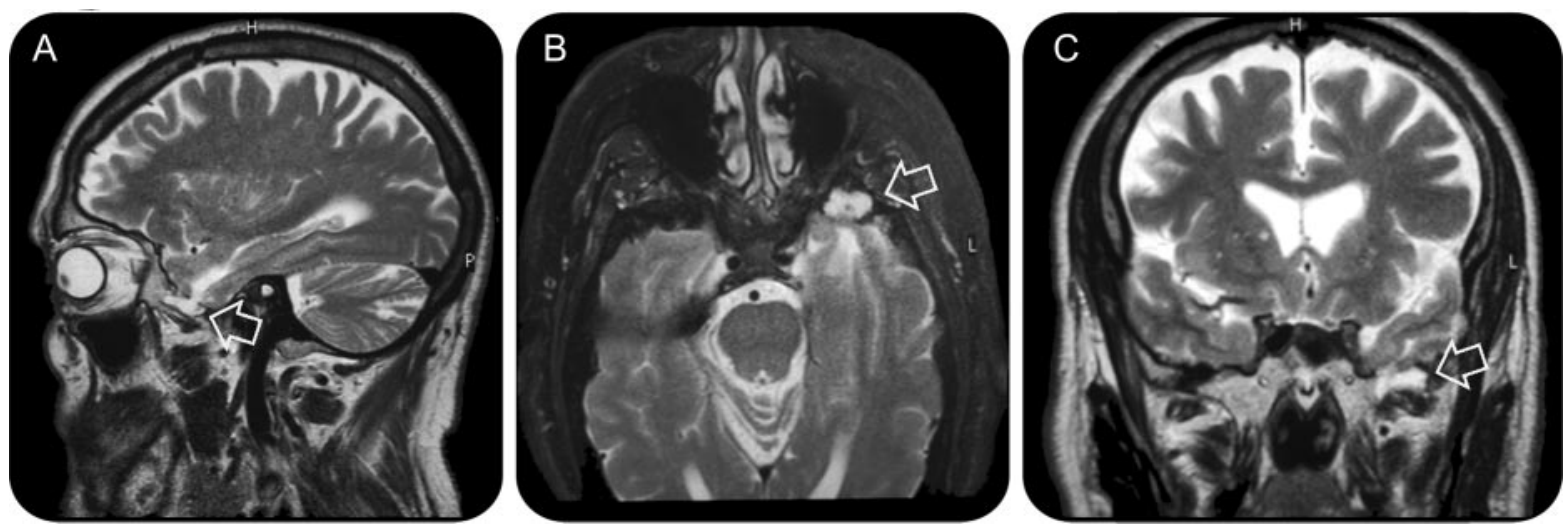

T2-weighted MRI scans in the sagittal (A), axial (B), and coronal (C) planes. A meningoencephalocele is visible in the middle cranial fossa with expansion ahead of the temporal ventricular horn (arrows). In the coronal scan (C) focal hippocampal atrophy is evident.

From the Departments of Neurosciences (G.D.M., S.D., F.P., P.P., A.L., E.T., S.C., V.G., V.D.) and Bioimaging and Radiological Sciences (C.C.), Catholic University, Rome, Italy.

Disclosure: Dr. Della Marca, Dr. Dittoni, Dr. Pilato, Dr. Profice, Dr. Losurdo, Dr. Testani, Dr. Colicchio, and Dr. Gnoni report no disclosures. Dr. Colosimo serves on the editorial advisory board of La Radiologia Medica and serves as a consultant for Bracco Diagnostics, Inc. and Bayer Schering Pharma. Dr. Di Lazzaro serves on a scientific advisory board for Medtronic, Inc.; serves on the editorial boards of Clinical Neurophysiology and Brain Stimulation and as editor of Case Reports in Medicine; and receives research support from Institut des Recherches Internationales Servier. 


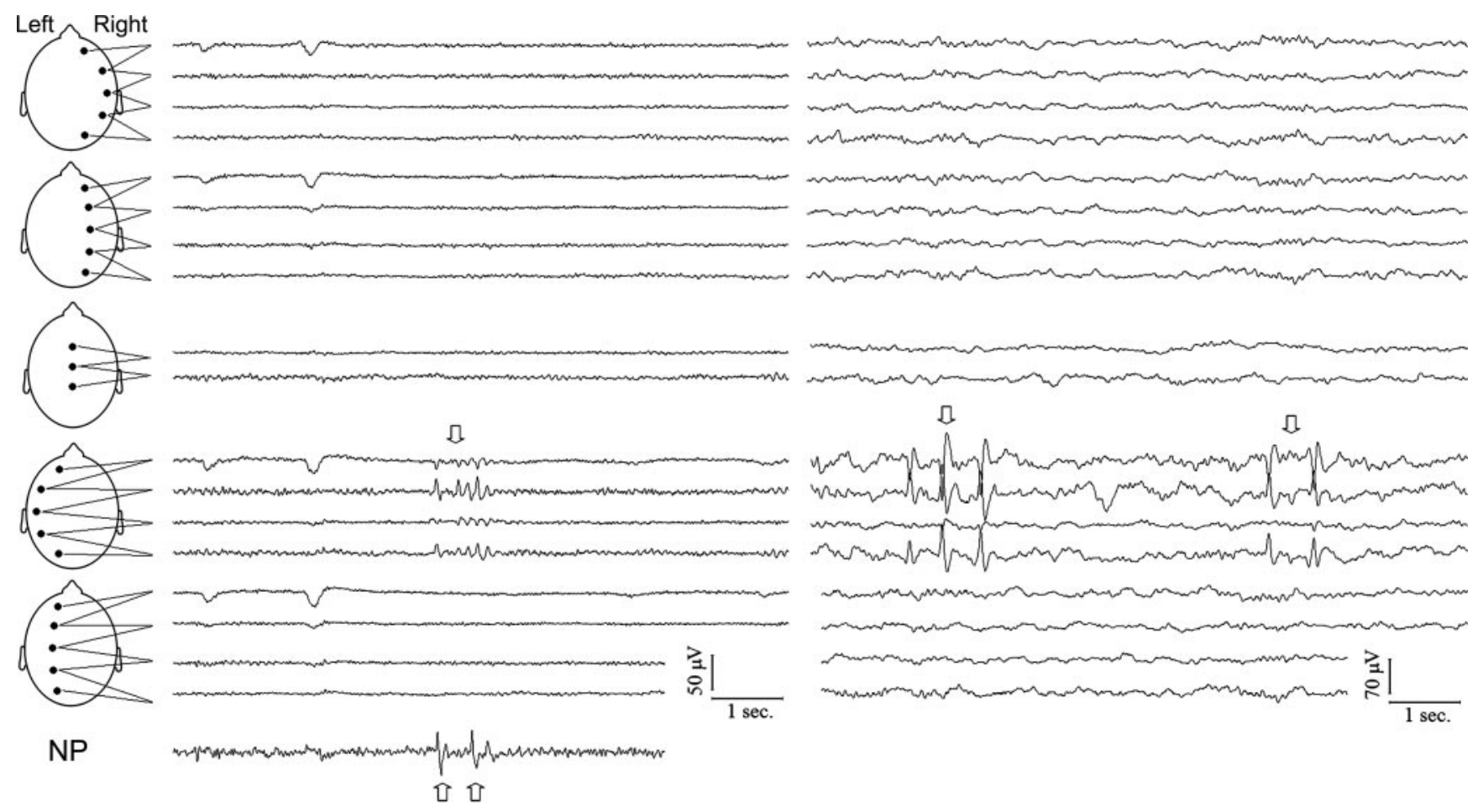

Scalp and nasopharyngeal (NP) EEG recording in wake (left panel) and during sleep stage N2 (right panel). Sharp waves and spikes are evident in left temporal leads and, particularly, in the nasopharyngeal recording during wake. No symptom was reported during the recording. Calibrations and time scales are in the lower right corners. 


\title{
Neurology
}

\author{
Teaching NeuroImages: Transient epileptic amnesia \\ G. Della Marca, S. Dittoni, F. Pilato, et al. \\ Neurology 2010;75;e47-e48 \\ DOI 10.1212/WNL.0b013e3181f11d9c
}

This information is current as of September 6, 2010

\section{Updated Information \& Services}

References

Subspecialty Collections

Permissions \& Licensing

Reprints including high resolution figures, can be found at: http://n.neurology.org/content/75/10/e47.full

This article cites 2 articles, 0 of which you can access for free at: http://n.neurology.org/content/75/10/e47.full\#ref-list-1

This article, along with others on similar topics, appears in the following collection(s):

All Epilepsy/Seizures

http://n.neurology.org/cgi/collection/all_epilepsy_seizures Cortical localization

http://n.neurology.org/cgi/collection/cortical_localization EEG; see Epilepsy/Seizures

http://n.neurology.org/cgi/collection/eeg_see_epilepsy-seizures

Memory

http://n.neurology.org/cgi/collection/memory

MRI

http://n.neurology.org/cgi/collection/mri

Information about reproducing this article in parts (figures,tables) or in its entirety can be found online at:

http://www.neurology.org/about/about_the_journal\#permissions

Information about ordering reprints can be found online:

http://n.neurology.org/subscribers/advertise

Neurology ${ }^{\circledR}$ is the official journal of the American Academy of Neurology. Published continuously since 1951, it is now a weekly with 48 issues per year. Copyright. All rights reserved. Print ISSN: 0028-3878. Online ISSN: 1526-632X.

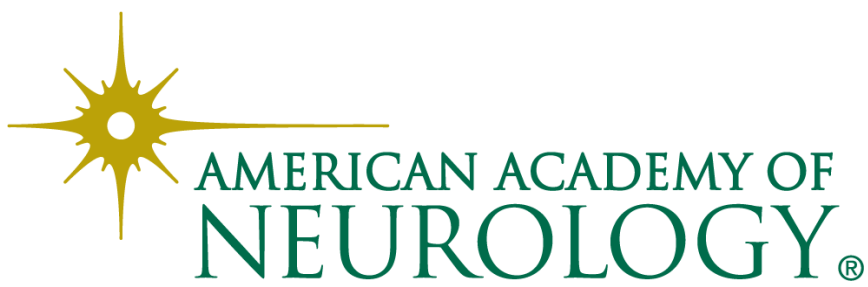

